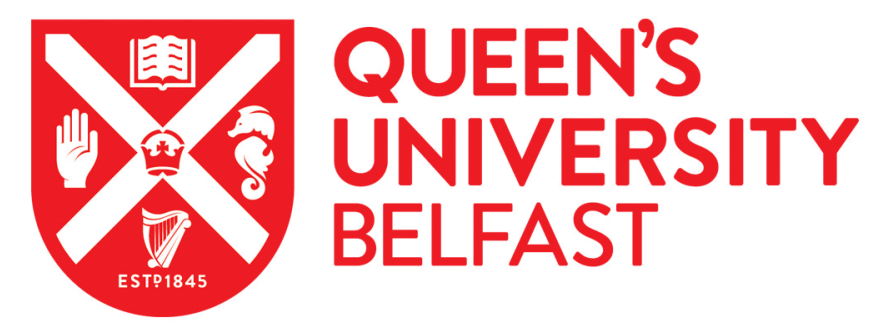

\title{
Reparations for the Transatlantic Slave Trade and Historical Enslavement: Linking past atrocities with contemporary victim populations
}

Moffett, L., \& Schwarz, K. (2018). Reparations for the Transatlantic Slave Trade and Historical Enslavement: Linking past atrocities with contemporary victim populations. Netherlands Quarterly of Human Rights. https://doi.org/10.1177/0924051918801612

\section{Published in:}

Netherlands Quarterly of Human Rights

\section{Document Version:}

Peer reviewed version

Queen's University Belfast - Research Portal:

Link to publication record in Queen's University Belfast Research Portal

\section{Publisher rights}

(C) 2018 The Authors.

This work is made available online in accordance with the publisher's policies. Please refer to any applicable terms of use of the publisher.

\section{General rights}

Copyright for the publications made accessible via the Queen's University Belfast Research Portal is retained by the author(s) and / or other copyright owners and it is a condition of accessing these publications that users recognise and abide by the legal requirements associated with these rights.

Take down policy

The Research Portal is Queen's institutional repository that provides access to Queen's research output. Every effort has been made to ensure that content in the Research Portal does not infringe any person's rights, or applicable UK laws. If you discover content in the Research Portal that you believe breaches copyright or violates any law, please contact openaccess@qub.ac.uk. 


\title{
Reparations for the Transatlantic Slave Trade and Historical Enslavement: Linking past atrocities with contemporary victim populations
}

\author{
Luke Moffett* and Katarina Schwarz**
}

Reparations are often seen as victim-centred measures to address past atrocities, but how far in the past should such remedies stretch? This question is perhaps most pronounced with the transatlantic slave trade, which is now accepted as a horrendous atrocity, but at the time was legal and victims were not redressed. Although reparations have a strong basis in international law since the Second World War, governments often adopt such measures through political settlements to draw a line under the past and provide new opportunities for victims. Reparations, at least in the legal arena, can embody a contention between societal feasibility and individual and/or group rights to a remedy for harm caused to them. Yet the extent to which legal and political measures of reparations can address the past is strained, due to the size of the victim population and how long ago historic violations were committed.

In 2013 the Caribbean Heads of State created the CARICOM Reparations Commission to advance the case for reparations for the transatlantic slave trade. In 2014 the Commission launch a Ten Point Plan for reparations that seeks 'to provide resources to victimized groups with the aim of creating the material basis and security necessary for them to become full participants in social, political, and economic life.' ${ }^{1}$ The demands focus on: (1) full formal apology; (2) repatriation; (3) indigenous peoples development program; (4) cultural institutions; (5) public health crisis; (6) illiteracy eradication; (7) African knowledge program; (8) psychological rehabilitation; (9) technology transfer; and (10) debt cancellation. These proposals for a comprehensive reparations package dealing with the horrors of transatlantic enslavement by the Caribbean Community (CARICOM) move away from the traditional reparations claim for these injustices in the United States - the demand for ' 40 acres and a mule, 2 to more collective reparations aimed at delivering closure and reparatory justice, not only for the so-called 'transatlantic slave trade', but also for the consequences of colonialism and genocide against indigenous people. ${ }^{3}$ These proposals are the result of a long line of discussions amongst Caribbean and African states on reparations for the transatlantic slave trade that started at the international level in Abuja, Nigeria in April 1993 at First Pan-African Congress on Reparations and later in 2001 United Nations World Conference against Racism, Discrimination, Xenophobia, and

\footnotetext{
* Senior lecturer, School of Law, Queen's University Belfast. Email: 1.moffett@qub.ac.uk

** PhD Candidate, School of Law, University of Nottingham. Email: Katarina.Schwarz@nottingham.ac.uk

${ }^{1}$ Ernesto Verdeja, A Normative Theory of Reparations in Transitional Democracies, Metaphilosophy 37(3-4) (2006), 449-469, p457.

2 Special Field Orders, No. 15, Headquarters Military Division of the Mississippi, 16 Jan. 1865, Orders and Circulars, series 44, Adjutant General's Office, Record Group 94, National Archives.

3 Caribbean Community's 10-Point $\quad$ Reparation Plan available at http://caricomreparations.org/caricom/caricoms-10-point-reparation-plan/ accessed 10 December 2016.
} 
Related Intolerance in Durban South Africa. ${ }^{4}$ While the claim for reparations at Durban was strongly rejected by Western states, it continues to be pursued by Caribbean nations through CARICOM, aiming to tackle the contemporary consequences of historical abuse committed against their ancestors during the transatlantic slave trade. ${ }^{5}$

This article takes a socio-legal approach drawing from human rights law, victimology, private law and transitional justice to examine the case of claim reparations for historic violations. It argues that while a collective approach to reparations as promoted by CARICOM is likely to be more palatable for responsible states, and more workable in legal terms, there remain serious legal challenges in finding sufficient evidence of a causal nexus between contemporary suffering and historical wrongs to satisfy judicial requirements. Paired with the difficulty of establishing that the wrongdoing was prohibited in law at the time the acts were committed, this leads away from the conclusion that a legal claim would be successful. However, in political terms specific evidentiary requirements and the distinction between law and morality can be more flexible, allowing claims which might not succeed on the basis of legal doctrine to conclude on the basis of justice. The CARICOM claim targets the modalities of reparations to respond to the contemporary consequences of transatlantic enslavement. A political settlement drawing from the experience of transitional justice is therefore likely to be more appropriate in providing redress. As such, this article critically assesses the CARICOM claim for reparations, and suggests appropriate measures if political reparations were to be made.

We explore these issues in four parts. First we examine reparations as justice and their construction in international law, discussing growing victimological understanding of redress for international crimes. In the second part we identify the continuing limitations of reparations being claimed under current legal regimes whether domestic or international. We broaden this examination by considering reparations as a political project in the third part, discussing other political settlements made for historical atrocities. In the final part we reflect on the possibilities of reparations for the transatlantic slave trade and historic enslavement before concluding. While we argue that the possibility for reparations for the transatlantic slave trade on a legal basis is unlikely, we do believe that in setting aside the legal lens on dealing with historic atrocities, there can be a larger space for states involved in the transatlantic slave trade on a moral and political basis to recognise the harm caused and make symbolic reparations. Of course this does not have the same force or binding as law, it would allow acknowledgement of the wrongfulness of the trade and greater focus in addressing the long term consequences of the transatlantic slave trade.

\footnotetext{
${ }^{4}$ V. P. Franklin, Commentary - reparations as a development strategy of the Caricom Reparations Commission, The Journal of African American History, 98(3) (20,363-366. See also para.100-102 of the Durban Declaration. ${ }^{5}$ See para.13-18, Durban Declaration 2001.
} 


\section{REPARATIONS AS JUSTICE}

Reparations are premised on the attempt to redress wrongful acts. Rather than seeking distributive justice or absolute equality, legal reparations focus on providing a remedy for specific acts of wrongdoing with identifiable victims and perpetrators. Reparations in this legal context, serve a tripartite function in satisfying the demands of justice by: vindicating the law; placing obligations to repair on the shoulders of responsible actors; and providing for the needs of the victims by redressing their suffering and manifesting their right to a remedy for breaches of their rights. Justice demands that breaches of law be met with an appropriate remedy, and reparations as a justice mechanism are a means by which this can be comprehensively granted. Reparations, extending beyond mere compensation, are constituted of three key elements: acknowledgement; responsibility; and remedy. ${ }^{6}$ They therefore reflect the totality of situations of wrongdoing and victimisation, rather than simply addressing the consequences.

Within a rectificatory framework, justice requires the return of the victim and the perpetrator to equality by removing any unlawful gain from the perpetrator and returning it to the victim, a sort of transactional arrangement. ${ }^{7}$ Restitutionary justice, as a form of this, attempts to return victims to the status quo ante (original position) through restitutio in integrum (returning to the victim all they have lost). The Chorzow Factory case demonstrates the primacy of the principle of restitution in integrum in international law:

reparations must, as far as possible, wipe-out all the consequences of the illegal act and re-establish the situation which would, in all probability, have existed if that act had not been committed. ${ }^{8}$

However, when dealing with massive, widespread, or severe abuses, the principle of restitutio in integrum becomes increasingly unfeasible. It is impossible to return victims to the positions that they would have been in but for the wrongdoing. ${ }^{9}$ As Minow identifies, 'no market measures exist for the value of living an ordinary life, without nightmares or survivor guilt'. ${ }^{10}$ At best reparations can never completely 'efface' the harm caused, but they can at least alleviate continuing suffering and loss, ${ }^{11}$ or

\footnotetext{
${ }^{6}$ See Luke Moffett, Justice for Victims before the International Criminal Court, (Routledge 2014), p145.

${ }^{7}$ See Aristotle, Nicomechean Ethics, Book V.

${ }^{8}$ Germany v Poland, The Factory at Chorzow (Claim for Indemnity) (The Merits), Permanent Court of International Justice, File E. c. XIII, Docket XIV:I Judgment No. 13, 13 September 1928 ('Chorzow Factory' case), para.125. See Article 31, Articles on State Responsibility for Internationally Wrongful Acts, ILC 2001.

${ }^{9}$ Factory at Chorzów, Merits, p.48.

${ }^{10}$ Martha Minow Between Vengeance and Forgiveness: Facing History After Genocide and Mass Violence (Beacon Press, 1998).

${ }^{11}$ Separate Opinion Of Judge Cançado Trindade, Ahmadou Sadio Diallo (Republic of Guinea v. Democratic Republic of the Congo), Compensation, Judgment, I.C.J. Reports 2012, p. 324, para.26.
} 
offer the opportunity and means for victims to build new lives. ${ }^{12}$ In relation to enslavement, it would be inappropriate to base reparations on the notion of return to the status quo ante, as redress to those who directly suffered would be 'impossible, insufficient, and inadequate'. ${ }^{13}$ Moreover, returning the individual to their personal and property rights before the violation would neglect the more structural causes of victimisation, marginalisation and discrimination. ${ }^{14}$ Nevertheless, reparations based on dealing with the continuing harms and recognition of the moral wrongdoings perpetrated may still be appropriate. $^{15}$

The intergenerational nature of claims relating to historical injustices erodes the basis of reparations claims. Identifying a causal nexus between the continuing suffering of contemporary descendants and the original wrongdoing becomes increasingly difficult as time passes. In the case of racialised transatlantic enslavement, intervening factors also contribute to the harms experienced by descendants - apartheid, colonialism, black codes, segregation, international debts and other discriminatory practices all contribute to current suffering in a way that at least obscures, and at most completely overrides, the historically based claims. Judicial practice tends to recognise the claims of direct victims and their immediate family (children, spouses, parents and sometimes siblings), but rarely strays beyond these limits on claimants. ${ }^{16}$ Hill argues that compensatory justice seems inappropriate past one generation, the passage of time mitigates the physical harm or is accommodated, but there may still be grounds for claiming restitution of property or unjust enrichment for the non-payment of labours of ancestors. ${ }^{17}$ This approach denies the broader impact of injustices on families and communities, acknowledging only the harms to the direct victims, and perhaps their next-of-kin.

While individual physical harm may be accommodated within a generation, systematic and structural abuses that continue to harm subsequent generations do not necessarily naturally change over time, and may reinforce disenfranchisement and discriminatory practices towards such groups and communities. An increasing body of psychological research supports the transgenerational impact

\footnotetext{
${ }^{12}$ Such as the 'proyecto de vida' (life project) established for a time by the Inter-American Court of Human Rights in Loayza Tamayo $v$ Peru, paras 147-148.

${ }^{13}$ Blake v Guatemala, Reparations (Article 63.1 of the Inter-American Convention on Human Rights), Judgment of January 22, 1999. Series C No. 48, para.42.

${ }^{14}$ Heidi Rombouts and Stephan Parmentier, The International Criminal Court and its Trust Fund are Coming of Age: Towards a Process Approach for the Reparation of Victims, International Review of Victimology 16 (2009) 149-182.

${ }^{15}$ Cristian Correa, Reparations for Victims of Massive Crimes: Making Concrete a Message of Inclusion, in in R. Letschert, R. Haveman, A.M. de Brouwer, and A. Pemberton (eds), Victimological Approaches to International Crimes: Africa (Intersentia 2011), 185-234, p189-190.

${ }^{16}$ See for instance the Swiss Holocaust Settlement experience - Judah Gribetz and Shari C. Reig, The Swiss Banks Holocaust Settlement, in C. Ferstman, M. Goetz, and A. Stephens (eds.), Reparations for Victims of Genocide, War Crimes and Crimes against Humanity: Systems in Place and Systems in the Making, (Martinus Nijhoff 2009), 115-142.

17 See René A. Hill, Compensatory Justice: Over Time and Between Groups, The Journal of Political Philosophy, 10(4) (2002), 392-415; and Jeremy Waldron, Redressing Historic Injustice, The University of Toronto Law Journal 52 (2002), 135-160.
} 
of unaddressed collective violence, whether this continuing influence manifests in terms of economic hardship, psychological health, physical health, or through its effects on carer responsibilities for children and grandchildren of direct victims. ${ }^{18}$ The increasing focus on rehabilitation and the medicalisation of victims' harm, may recast victims as sick, rather than wronged. Whether the law is an appropriate mechanism for redressing such harms remains debateable, as the typical focus of judicial proceedings relies on the relationship between a perpetrator or responsible actor and each victim as an individual. Arendt goes so far as to say that the scale of mass atrocities 'explode the limits of the law, ${ }^{19}$ and that courts and their legal principles designed to deal out ordinary justice are insufficient to grapple with such atrocities.

In attempting to make the incomprehensible justiciable, courts can serve as empowering mechanisms whereby the individual agency and rights of victims are recognised and vindicated. On the other hand, the focus on the individual's rights can undermine the gravity of the holistic experience of atrocities that target groups, communities or populations. The tendency of legal proceedings to individualise victims can ignore important elements of the suffering of the victims: atrocities were committed on a large scale; they were targeted for some aspect of their fundamental identity; or they were denied humanity on the basis of particular, morally arbitrary characteristics. Courts can provide victims with an official forum in which their stories are heard and recognised; the value of testimony in fostering psychological healing for victims of atrocities is significant. ${ }^{20}$ Yet, the appropriateness of court proceedings for accomplishing such healing and redress faces a number of limitations discussed further below.

Reparations are not purely (or even necessarily primarily) concerned with practical redress, they also have an important symbolic component in that they can 'acknowledge and recognise the individual's suffering ... can help concretise a traumatic event, aid an individual to come to terms with it and help label responsibility. ${ }^{21}$ Traumatic suffering is characterised by the inability to come to terms with an experience as it occurs, reinforcing the importance of efforts aimed towards acknowledgement and memory building. ${ }^{22}$ Reparations in this context can reflect 'social, moral, psychological and religious meanings' attached to official efforts to redress the past, such as public apologies and acknowledgement of responsibility, memorials and commemorations. ${ }^{23}$ Such public

\footnotetext{
18 Marie Breen-Smyth, The needs of individuals and their families injured as a result of the Troubles in Northern Ireland, WAVE Trauma Centre (2012); Yael Danieli, Massive Trauma and the Healing Role of Reparative Justice, in Ferstman n.12, 41-78.

19 L. Kohler and H. Saner (eds), Hannah Arendt and Karl Jaspers: Correspondence: 1926-1969, (Harcourt Brace International 1992), p54.

${ }^{20}$ Danieli n.14, p45.

${ }^{21}$ Brandon Hamber, Repairing the irreparable: Dealing with the double-binds of making reparations for crimes of the past, Ethnicity and Health 5(3/4) (2000) 215-226, p218.

${ }^{22}$ Cathy Caruth, Trauma: Explorations of Memory (John Hopkins University Press, 1995), p70.

23 Geneviève Painter, cited in Anne Saris and Katherine Lofts, Reparation Programmes: A Gendered Perspective, in Ferstman et al. n.12, 79-99, p86.
} 
recognition and physical space can help victims in their grieving process by offering focal points that maintain the memory of their loved one.

Through symbolic redress, reparations can also speak to the moral harms caused by victimisation - the intangible damage to individual, collective and cultural identity - and aid in reasserting the status of victims in their relationship with society and/or the perpetrator(s). As Herman states:

Sharing the traumatic experience with others is a precondition for the restitution of a sense of a meaningful world...Restoration of the breach between the traumatized person and the community depends, first, upon public acknowledgement of the traumatic event and, second, upon some form of community action. Once it is publicly recognized that a person has been harmed, the community must take action to assign responsibility for the harm and to repair the injury. These two responses - recognition and restitution - are necessary to rebuild the survivor's sense of order and justice. ${ }^{24}$

Particularly in transitional societies, reparations can serve a political function in rebuilding the victim's 'civic trust' with other citizens and in the state, and reaffirming their dignity by prioritising their suffering as deserving of redress. ${ }^{25}$ This sits in stark contrast to the past where they were vilified, dehumanised and targeted. In building this new political community, social solidarity and inclusion is extended to victims as citizens entitled to a remedy. While of course there are not enough resources to fully or completely remedy victims' harm, Hamber suggests the notion of 'good enough', whereby sufficient effort and recognition is made to victims to leave them psychologically satisfied, in turn rebuilding community and societal bonds. ${ }^{26}$

As a victim-centred form of redress with both material and symbolic components, reparations are not only driven by outcomes, but also by procedural roles and the inclusivity of awards. Procedural justice is concerned with improving victims' satisfaction with state programmes, mainly criminal justice processes, by treating them fairly, with respect and in such a way that they will perceive that their input is valued. ${ }^{27}$ Allowing time and space within procedures for victims to be heard (even when this is not a formal requirement of, for instance, trial procedures) can support recognition of their experiences, and the reassertion of their identity and place in society. Official

\footnotetext{
${ }^{24}$ Judith Herman, Trauma and Recovery: From Domestic Abuse to Political Terror, (Rivers Oram Press, 1994), p70.

${ }^{25}$ Lisa Magarrell, Reparations for massive or widespread human rights violations: Sorting out claims for reparations and social justice, Windsor Yearbook of Access to Justice 22 (2003) 85-98, p91.

${ }^{26}$ Brandon Hamber, The dilemmas of reparations: In search of a process-driven approach, in K. De Feyter, S. Parmnetier, M. Bossuyt and P. Lemmens (eds.), Out of the Ashes: Reparation for Victims of Gross and Systematic Human Rights Violations (Intersentia 2005), 135-149, p137.

${ }^{27}$ Jo-Anne Wemmers, Victims' Need for Justice in R Letschert et al. n.11, 145-152.
} 
acknowledgement of victims' 'world view' on their past victimisation, the causes that gave rise to it, and those responsible can be a way of affirming their dignity as human beings, recognising that they did not deserve to suffer such harm. Danieli goes as far to say that inclusion of victims in itself offers 'an opportunity for redress and healing, ${ }^{28}$ In this way, the procedures through which reparations are granted can acknowledge the importance of victims' agency and worth, and victims thereby have an important role to play in shaping appropriate reparations.

Including victims as active participants in reparations procedures is particularly important in the context of gross violations of human rights where victims are denied basic humanity through the abuses, and where impunity often attaches to wrongdoing (particularly in transitional societies and when official actors played a role in the abuses).$^{29}$ The nature and subsequent treatment of the abuses, and the need to maintain public order can silence and obviate victims, denying the occurrence or severity of their harm. Ensuring the involvement of victims in redress processes can ensure that their experiences are recognised, their rights are vindicated, and their needs are incorporated into any reparations packages. Despite the normative growth and theoretical development of reparations, there remain a number of legal challenges to seeking redress for the transatlantic slave trade.

\section{THE LIMITS OF REPARATIONS UNDER INTERNATIONAL LAW}

The possibility of pursuing a case claiming reparations for the transatlantic slave trade in domestic courts is severely inhibited by the difficulties associated with mass claim actions, time limits on claims, rules on standing and separation of powers based principles, such as the political question doctrine in the United States. ${ }^{30}$ The scale and collective nature of the harms in question, on top of these impediments, make international law the only likely forum for such a reparations claim. However, international law has many hurdles of its own. Here we identify three main obstacles in domestic and international law that will inhibit or prevent reparations claims for the transatlantic slave trade and historic enslavement: non-retroactivity; causation; and attribution of responsibility.

\subsection{Non-Retroactivity}

By today's standards, the transatlantic slave trade and historic enslavement would undoubtedly amount to a crime against humanity. ${ }^{31}$ However international law, like domestic law, enshrines the principle of non-retroactivity as a fundamental tenet of the legal system. ${ }^{32}$ The Articles on State Responsibility, for instance, guarantee protection against retrospective application of international

\footnotetext{
${ }^{28}$ Danieli n.14, p66.

${ }^{29}$ Luke Moffett, Transitional Justice and Reparations: Remedying the Past?, in C. Lawther, L. Moffett and D. Jacobs, Research Handbook on Transitional Justice, Elgar (forthcoming 2017).

${ }^{30}$ See In re African-American Slave Descendants Litigation 471 F.3d 754 ( $7^{\text {th }}$ Cir. 2006).

${ }^{31}$ Article 7(1)(c), Rome Statute of the International Criminal Court.

32 Article 15, International Covenant on Civil and Political Rights; and Article 24, Rome Statute of the International Criminal Court.
} 
law, stipulating that 'An act of a State does not constitute a breach of an international obligation unless the State is bound by the obligation in question at the time the act occurs. ${ }^{33}$ In order to found a legal claim for reparations, it must therefore be established that the acts in question were contrary to international law at the time that the acts were committed. This is not supported under current conceptions of the development of the prohibition of slavery, which is generally recognised as having come into existence in $1926 .^{34}$

Although morally repugnant, slavery was legal and regulated under domestic law of the time, as well as the tentative 'international' law of the time. ${ }^{35}$ The dominance of this understanding of the status of prohibition is apparent in a number of cases before Umpire Bates of the United States-Great Britain Mixed Commission involving the actions of British authorities who seized US ships involved in the slave trade and freed slaves belonging to US nationals. Umpire Bates had to determine whether slavery was 'contrary to the law of nations' at the time of each incident in order to determine whether the British state had committed acts of unlawful interference with the property of foreign nationals in freeing the American slaves. The commission found such unlawful interference in cases preceding recognised prohibition, but later found no breach once the slave trade was recognised as being 'prohibited by all civilized nations' ${ }^{36}$

International law is primarily premised on the consent of State Parties to the rules contained therein. It is therefore important that there has been consensus achieved through the conclusion of treaties or, as du Plessis points out, that international law has crystallised around an issue through wide state practice and observance - principles of morality are insufficient as a basis of international prohibitions. ${ }^{37}$ Unlike the initial codification of international criminal law through the Nuremberg Tribunal, there was no 'defining moment' in the criminalisation of slavery. ${ }^{38}$ Shelton acknowledges that 'slavery became illegal under international law slowly and in piecemeal fashion, starting over a century after the transatlantic slave trade began and as a result of opposition that existed from the start and grew stronger over time. ${ }^{39}$ The fact that transatlantic enslavement was an abhorrent act at the time cannot therefore, in itself, serve as the basis of legal liability, nor can the now recognised special status of the prohibition against slavery in international law. Even the jus cogens (non-derogable)

\footnotetext{
${ }^{33}$ Article 13, Articles on State Responsibility for Internationally Wrongful Acts.

${ }^{34}$ Slavery Convention 1926, League of Nations Treaty Series, vol. 60, p.253-270. Rhoda E. Howard-Hassmann and Anthony P. Lombardo, Framing Reparations Claims: Differences between the African and Jewish Social Movements for Reparations, African Studies Review 50(1) (2007), 27-48, p30.

${ }^{35}$ See Jean Allain, Slavery in International Law (MNP, 2013).

${ }^{36}$ See Commentaries to the Draft Articles on Responsibility of States for Internationally Wrongful Acts, Report of the International Law Commission on the work of its fifty-third session (2001), p57-58.

37 Max du Plessis, Historical Injustice and International Law: An Exploratory Discussion of Reparation for Slavery, Human Rights Quarterly, 25(3) (2003), 624-659, p634.

${ }^{38}$ Geoffrey Robertson, Crimes against Humanity: The Struggle for Global Justice, (Penguin 2000), p209.

${ }^{39}$ Dinah Shelton, Remedies in International Human Rights Law (OUP 2005, 2nd edn.), p443.
} 
nature of the prohibition against slavery cannot obviate the principle of non-retroactivity of responsibility. ${ }^{40}$

Even if there were a legal basis for reparations on the transatlantic slave trade, there would be limits on the scale of such redress. Reparations under international law are not limitless. The Articles on State Responsibility are couched in terms of proportionality with restitution only granted where it is not 'materially impossible' or would 'involve a burden out of all proportion to the benefit deriving from restitution instead of compensation. ${ }^{41}$ This of course does not prevent states from agreeing to political settlements over historic injustices, it only prevents the international legal order being used as a remedial avenue.

\subsection{Causation}

It is a general principle of private, criminal and international law that harm caused to a victim capable of being redressed through judicial mechanisms must be the result of a wrong or crime committed by the responsible party on trial. ${ }^{42}$ As a legal construct, reparations do not seek to address all suffering, but rather the specific damages which result from particular wrongdoing; compensable harms are those sufficiently proximate consequences which are causally connected to the illegal acts in question. The nature of this causation for claims of reparations in law requires a victim to have suffer in fact from a wrong committed by a responsible party, with sufficient legal rules to permit such a wrong to give rise to a legal cause. The Articles on State Responsibility do not define the causal link required to found a legal claim, as different areas of international law contain obligations of a different nature. ${ }^{43}$ However, the commentaries do note that factual causation alone is not the sole criterion. ${ }^{44}$ This makes it clear that there is a distinction in the law between factual and legal causation.

Factual causation is established by a direct connection between the wrongs in question and the damages suffered as a result of the wrong in question. In other words, the harm would not have occurred, but for the wrongdoing. Factual causation may be easily proved in relation to direct victims of injustice, but it becomes increasingly difficult to identify as time passes and other factors interact with the original wrongdoing to perpetrate and perpetuate harm. Howard-Hassmann and Lombardo, comparing reparations claims for the Jewish Holocaust with those relating to transatlantic enslavement, note that the causal nexus between direct victims and those responsible was more apparent in the first wave of claims against the Nazi government only a few years after the Holocaust,

\footnotetext{
40 Barcelona Traction, Light and Power Company, Limited (Belgium v Spain) (Judgement) (Merits), International Court of Justice, ICJ GL No 50, [1970] ICJ Rep 3, 5 February 1970 (Barcelona Traction case), para. 34; Du Plessis, n.33, p636; and para.5-6, ILC commentaries.

${ }^{41}$ Article 35(a)-(b), article 37(3). See Du Plessis n.33, p630.

${ }^{42}$ For instance, Article 75(2) of the Rome Statute.

43 James Crawford The International Law Commission's Articles on State Responsibility (Cambridge University Press 2002), p492-3, and para.10.

${ }^{44}$ ILC Commentaries, para. 10.
} 
which became more difficult for more indirect victims in subsequent years. ${ }^{45}$ For instance with subsequent claims in the 1990s against private corporations such as Swiss banks, the harm was more removed as many of the direct survivors had died, and it was their next-of-kin or heirs making claims.

Ultimately, the Swiss banks Holocaust settlement recognised that not all heirs for the purpose of personal injury claims should be eligible for compensation as it would dilute the amount of money available to those directly harmed given the limited nature of the funds. ${ }^{46}$ Although this conclusion resulted in large part from the financial limitations of the situation, a clear distinction was drawn between direct and subsequent victims premised on the strength and proximity of the causal nexus. This would pose even greater challenges in reparation claims for transatlantic enslavement, as these have passed through several additional generations than had the claims in the Swiss banks settlement.

Legal causation seeks to establish not only which consequences are connected to the wrongdoing, but which connected harms ought to be redressed by the wrongdoer in any given case. Legal causation therefore requires an assessment of remoteness, foreseeability, and proximity. ${ }^{47}$ Remoteness and proximity are both premised on the notion that the consequences of any human act are far-reaching, potentially infinite, and often impossible to accurately assess. Given the scale of the transatlantic slave trade as with other contemporary international crimes, the scale and extent of harm can stretch the limits of the law and adequacy of remedies, therefore there must be some form of limits on what redress is possible and feasible. As the Inter-American Court of Human Rights stated:

Every human act produces diverse consequences, some proximate and others remote. An old adage puts it as follows: causa causæ est causa causati. Imagine the effect of a stone cast into a lake; it will cause concentric circles to ripple over the water, moving further and further away and becoming ever more imperceptible. Thus it is that all human actions cause remote and distant effects. To compel the perpetrator of an illicit act to erase all the consequences produced by his action is completely impossible, since that action caused effects that multiplied to a degree that cannot be measured. ${ }^{48}$

The law must therefore draw a distinction at some point between proximate and remote harms, in order to avoid infinitely varying and ethereal consequences coming within the purview of a specific cause of action. The principle of foreseeability is embedded in the bilateral nature of judicial proceedings: claims are not only constituted by victims, but are levied against a specific actor who is

\footnotetext{
${ }^{45}$ Howard-Hassmann and Lombardo n.30

${ }^{46}$ Gribetz and Reig n.12.

${ }^{47}$ Administrative Decision No. II, United States-Germany Claims Commission, ibid; Dix, American-Venezuela Commission, 9 R.I.A.A. 119 (1902) at 121; War-Risk Insurance Premium Claims, 7 R.I.A.A. 44 (1923) at 55.

${ }^{48}$ Aloeboetoe and others $v$ Suriname, Judgment of September 10, 1993 (Reparations and Costs), para.48.
} 
to be made liable for the consequences of his or her wrongdoing. ${ }^{49}$ Justice in the legal context is concerned with enforcing proportionate culpability on the offender as well as vindicating the rights of victims. As Shelton notes, '[t]he line drawn inevitably demands policy determinations about the reasonableness of expecting an actor to have foreseen the specific consequences of the action taken and about which party should most appropriately bear the loss. ${ }^{50}$

Despite requiring distinctions between compensable and non-compensable harms, rules regarding remoteness, proximity and foreseeability are not so restrictive as to provide redress only for direct harms - responsibility may be attributed on an indirect basis. Perpetrators may be held responsible for damages resulting from the actions of another, but which were the foreseeable and proximate consequence of the wrongdoing. Thus the Iraqi government was held responsible for 'any direct loss, damage, including environmental damage' suffered 'as a result of Iraq's unlawful invasion and occupation of Kuwait' - even in cases where Kuwaiti oil wells were hit by Coalition bombing. ${ }^{51}$ The extent of indirect liability can thus accommodate liability of a wrongdoer even where another, independent actor is more directly connected to the damage, provided that causation is established. In the case of the transatlantic slave trade the role of private organisations and individuals in the enslavement, transport, sale and use of individuals for slavery would have to be scoped, acknowledged and addressed by any proposed reparations programme.

The passage of time in and of itself can impact on establishing causation, as private law principles of attenuation or the existence of intervening acts can break a link in the chain of causation between the perpetrator's wrongdoing and the victims' harm. ${ }^{52}$ The principle of attenuation recognises that the more remote an action is from the claimed consequences, the more difficult it will be for a court to find a clear causal connection. Just as the impact of an illegal police procedure on evidence can 'become so attenuated as to dissipate the taint', ${ }^{53}$ so too can the effect of wrongdoing on a victim become so far removed over time as to destroy the causal nexus.

Intervening actions and events which impact upon the victim can similarly weaken the causal chain, and such events may be so significant as to completely override the original wrongdoing as a cause of current harms. In the case of enslavement of African people and their descendants in the United States, for instance, the institution of slavery was succeeded by segregation, lynching,

\footnotetext{
49 Naulilaa Case (Responsibility of Germany for damage caused in the Portuguese colonies in the south of Africa (Portugal v Germany), 2 R.I.A.A. 1011 (1928). See Conor McCarthy, Reparation for Gross Violations of Human Rights Law and International Humanitarian Law at the International Court of Justice, in Ferstman et al. n.12, 283-311 p297-298.

${ }^{50}$ Dinah Shelton, Righting Wrongs: Reparations in the Articles on State Responsibility, The American Journal of International Law 96(4) 92002), 833-856 p846.

${ }^{51}$ S/RES/687 (1991) 8 April 1991; and Report and Recommendations made by the Panel of Commissioners Appointed to Review The Well Blowout Control Claim (The "WBC CLAIM"), 18 December 1996, S/AC.26/1996/5/Annex, para.86.

${ }^{52}$ Kaimipono David Wenger, Causation and attenuation in the slavery reparations debate, University of San Francisco Law Review 40(2) (2006) 279-326.

${ }^{53}$ Nardone v United States, 308 US 338, 341, 60 S Ct 266, 84 L Ed 307 [1939].
} 
redlining, police brutality, and other forms of racial discrimination which severely impacted on the lives and outcomes of people of African descent in the US. ${ }^{54}$ This makes establishing the original enslavement as a continuing causative factor in contemporary suffering particularly difficult. As each generation passes, the causal connection further degrades posing increasing difficulties for the descendants of enslaved persons who are now several generations removed from the direct victims of enslavement and who are faced with a slew of intervening factors contributing to identified harms. However, these factors may be considered to diminish the impact of original wrongdoing upon the victims, rather than completely severing the chain of causation. In such a case, the amount of reparation or damages awarded could be reduced on the principle of mitigation.

\subsection{Attribution of Responsibility}

A legal claim for redress, premised on the need to do justice between wrongdoers and victims, requires the attribution of responsibility for wrongful acts to an extant legal entity or person. In civil cases, personal claims can only be brought in personam (against a person), barring such claims premised upon individual wrongdoing in relation to historical enslavement where no direct perpetrators survive. Actions in rem (against a thing) may be transmitted to actors other than the original perpetrator; however there are serious difficulties in constructing such claims in relation to enslavement generally as the primary rights sought to be vindicated do not relate to wrongs against property, but wrongs committed against persons. ${ }^{55}$ The claim for unjust enrichment based on the unpaid labour of enslaved persons seeks to create such an in rem action. This is proposed as crafting a constructive trust around the sum of money representative of the unpaid labour, and transmitting obligations in relation to such money down the lines of inheritance of successive generations. ${ }^{56}$ The doctrine of laches (lack of diligence in making a speedy claim), detrimental reliance and undue hardship principles, combined with the difficulty of tracing sufficient funds through multiple generations in the majority of cases would make claims against contemporary heirs near impossible in practice. ${ }^{57}$ Arguing for the transmission of the beneficial interest in the constructive trust would prove even more difficult in such a context, as no established right to inherit exists within the legal systems in question.

In the case of a claim against a state, continued responsibility is understood in terms of the rules of state succession. Because the political identity of the relevant European states has remained largely constant since the period of transatlantic enslavement, responsibility may be attributed to the

\footnotetext{
${ }^{54}$ Ta-Nehisis Coates, The Case for Reparations, The Atlantic, June 2014.

${ }^{55}$ See Jeremy Waldron, Superseding Historic Injustice, Ethics 103(1) (1992) 4-28.

${ }^{56}$ See George Schedler, Principles for Measuring the Damages of American Slavery, Public Affairs Quarterly, 16(4) (2002), 377-404, p397-398; and Stephen Kershnar, The Inheritance-Based Claim to Reparations, Legal Theory, 8 (2002), 243-267, p253.

57 See Lynton Tucker, Nicholas Le Poidevin and James Brightwell, Lewin on Trusts $\left(19^{\text {th }}\right.$ edn, Sweet and Maxwell 2015).
} 
governments of these states. In the Mau-Mau case against the United Kingdom government, the UK argued that atrocities committed by colonial government were attributable to Kenyan government. This argument was rejected on the grounds that there were comprehensive and voluminous records in the UK's Foreign and Commonwealth Office that detailed the role of the former War Office and Colonial Office in using torture to restore law and order in Kenya under the colonial administration. Moreover, despite a statute of limitations to time bar civil claims against responsible actors, ${ }^{58}$ the Mau Mau case was an exception given it was a settlement. The rules were also found to be more flexible with the court stating that there exists 'the widest possible discretion, within bounds, to enable claims for personal injury to proceed outside the general limitation period where the justice of the case so requires. 59

Establishing responsibility for companies, such as those who facilitated the transport of individuals into slavery, would be difficult in legal terms, given that many of these companies no longer exist or have changed ownership or merged with other corporations multiple times. Such basis for reparations may be on political ground given the public pressure that can be placed on slavery profiting companies, some of whom have funded scholarships to descendants of slaves. ${ }^{60}$ In addition, there are strict limits on individuals bringing civil cases against other states and state actors, given the rules on state immunity even for recent violations. ${ }^{61}$ Accordingly, the legal limitations inhibiting historical claims from successfully obtaining reparations within the judicial arena are significant, and the likelihood of a legal ruling in favour of such a case is limited. It may be more apposite to frame such reparation claims on a more political basis on the moral wrongfulness of the atrocities, which may require taking compensation off the table.

\section{REPARATIONS AS A POLITICAL SETTLEMENT}

Reparations in relation to severe, historical, and state-perpetrated injustices do not rise or fall only within the bounds of judicial systems. In such cases reparations can, and often are, constructed within the political arena where they are built as a political 'project' ${ }^{62}$ or 'settlement' for a class or group of victims. ${ }^{63}$ Judicially constructed reparations can respond to individual harms and the unique situations

\footnotetext{
${ }^{58}$ In the UK under the Limitation Act 1980.

${ }^{59}$ Mutua \& Ors $v$ The Foreign and Commonwealth Office, [2012] EWHC 2678 (QB), para.158. Section 33, Limitations Act 1980.

${ }^{60}$ For example JP Morgan Chase in 2005 apologised for its historical involvement in slavery, and announced that it was setting up the Smart Start Louisiana scholarship, providing an initial \$5 million (US) over a five year period for full tuition and undergraduate scholarships to black students from Louisiana to attend colleges in the state. JP Morgan admits US slavery links, BBC News, 21 January 2005, available at: http://news.bbc.co.uk/1/hi/business/4193797.stm accessed 10 December 2015.

${ }_{61}$ Jurisdictional Immunities of the State (Germany $v$ Italy: Greece intervening) (Judgment) [2012] ICJ Rep 99; and Case of Jones and Others $v$ The United Kingdom App nos. 34356/06 and 40528/06 (ECtHR, 14 January 2014).

62 Magarrell n.21, p94.

${ }^{63}$ Pablo de Greiff, Justice and Reparations, in P. de Greiff (ed.), Handbook of Reparations, (OUP 2006) 451$477, \mathrm{p} 454$.
} 
of different victims. However in doing so courts can disaggregate victims and cause discrepancies between reparations for victims in similar situations on the basis of available evidence and diverging decisions. ${ }^{64}$ Some victims are likely to be entirely excluded from judicial processes because of strict evidentiary burdens; standards which are particularly difficult to meet in the context of historical abuses or situations of civil unrest. Political reparations allow for evidentiary requirements to be eased reflecting the reality of the situation in question.

Reparations adopted as part of a transitional or historical redress of the past are positioned to send political and moral messages as to the wrongfulness of the harm caused to victims, vindicating their civic status and providing appropriate remedies as part of society's solidarity with their plight. ${ }^{65}$ According to de Greiff reparations can serve a truth-telling function by helping to clarify the past and 'awaken empathy with victims'. ${ }^{66}$ Hamber suggests that while reparations may not be comprehensive and full, where there is sufficient effort and recognition made to victims can be seen as 'good enough', leaving them psychologically satisfied, in turn rebuilding community and societal bonds. ${ }^{67}$

Five general principles assist in assessing the effectiveness of any reparations process: (1) completeness and comprehensiveness; (2) complexity and coherence; (3) appropriateness and proportionality; (4) acknowledgement; and (5) transformative justice. The first of these, completeness and comprehensiveness, involves as far as possible including all atrocities and victims who have suffered serious harm. ${ }^{68}$ This does not necessarily require the inclusion of all possible victims, but rather that the parameters of the reparations programme are clear. Completeness in this context refers to the coverage of relevant potential beneficiaries with consideration for the evidentiary standards imposed, and measures taken to ensure reparations are accessible. Comprehensiveness relates to the category of violated rights, which are redressed through a range of measures (restitution, compensation, rehabilitation, measures of satisfaction and guarantees of non-repetition) to address breaches of a wider variety of rights.

Secondly, reparations mechanisms are considered complex when they provide for different types of reparations, individual and collective measures. Such measures should be internally and externally coherent with the reparations order and complement other transitional justice approaches such as trials and truth commissions. ${ }^{69}$ Third, proportionality requires that the redress granted to the victims is reflective of the harms that they suffered as a result of the breach of their rights. Human rights reparation principles support that awards should not enrich or impoverish victims, but be equal

\footnotetext{
${ }^{64}$ Ibid., p458.

${ }^{65}$ Magarrell n.21, p91.

${ }^{66}$ de Greiff n.59, p464.

${ }^{67}$ Hamber n.22, p137.

${ }^{68}$ Pablo de Greiff, Repairing the Past: Compensation for Victims of Human Rights Violations, in de Greiff n.59, 1-16.

${ }^{69}$ Ibid., p10-11.
} 
to their harm..$^{70}$ Fourthly, acknowledgement 'symbolize[s] a society's undertaking not to forget or deny that a particular injustice took place, and to respect and help sustain a dignified sense of identity in memory for the people affected. ${ }^{, 71}$

Lastly, transformative justice moves toward tackling the structural causes of violence and victimisation, such as racial discrimination, rather than merely the symptoms. Gready and Robins point to transformative justice confronting social exclusion and focus on an inclusive process over outcomes as well as challenging unequal power relations. ${ }^{72}$ This approach would indicate a more consultative role for descendants of the transatlantic slave trade in redressing the continuing structural violations that they face. Some scholars consider transformative justice to align more closely to notions of distributive justice than to the restitutionary model of legal redress in its attempt to 'recognise unjust distributions of resources and seek to redistribute accordingly, ensuring that underlying causes of injustice are addressed. ${ }^{73}$ In many situations of grave or systemic injustice, it would be inappropriate to focus on the restitutionary objective of return to the status quo ante in constructing reparations as it is often that very paradigm which created the conditions from which the wrongdoing arose. Return would entail continued victimisation of those suffering the consequences of the abuses in such situations, and increase the likelihood of recurrence in the future. In the context of existing structural inequalities, the Inter-American Court of Human Rights recognised in Cotton Field $v$ Mexico that reparations should be designed to effect structural change and to redress the inequalities which gave rise or allowed for the wrongdoing to take place, stating:

bearing in mind the context of structural discrimination [against female victims]... the reparations must be designed to change this situation, so that their effect is not only of restitution, but also of rectification. In this regard, re-establishment of the same structural context of violence and discrimination is not acceptable. ${ }^{74}$

This concern with the causes of violence and the rectification of such moves reparations away from the strict implementation of the principle of restitutio in integrum and allows for a transformative approach within a judicial framework. Nevertheless the political process is more likely to be amenable to a flexible approach to the basis and assessment of awards, and to allow the infusion of transformative justice principles into the process. Political reparations processes, which are concerned with transformative justice, may thereby engender meaningful change for victims within their

\footnotetext{
${ }^{70}$ Garrido and Baigorria v Argentina, Judgment, Series C No. 39 (IACtHR, 27 August 1998), para.43.

${ }^{71}$ Waldron n.51, p6.

${ }^{72}$ Paul Gready and Simon Robins, From Transitional to Transformative Justice: A New Agenda for Practice, International Journal of Transitional Justice, 8, (2014), 339-361.

${ }^{73}$ Saris and Lofts, n.19, p93. Nairobi Declaration on Women's and Girls' Right to a Remedy and Reparation, March 2007, para.4.

${ }^{74}$ Case of Gonzáles et al. ("Cotton Field”) v. Mexico, Preliminary Objection, Merits, Reparations, and Costs, Judgment of 16 November 2009, para.450.
} 
particular social and political contexts in a manner which legal reparations are less apt to achieve. As such, effective reparations programmes should go beyond the direct, individualised redress provided for through court processes to address the circumstances and contributory factors of historical atrocities, rather than dealing only with the specific wrong and the resulting harm.

Processes constructed on transformative justice principles are more appropriate for dealing with transatlantic chattel enslavement, as the foundational premise and justification for the so-called 'trade' was the extreme racialisation and marginalisation of particular groups of people to be exploited for profit. The reincarnation of extreme inequality between people racialised as black and white through the decades following legal abolition of slavery belies the argument that the process of 'emancipation' in itself was transformative. Individuals would still be able to benefit from reparations, in that they would respond to individual needs for rehabilitation, such as counselling, but also be aimed at redressing wider common needs of descendants of the 'transatlantic slave trade'.

\section{REPARATIONS FOR TRANSATLANTIC SLAVE TRADE AND HISTORICAL ENSLAVEMENT}

When applying the rubric of reparations, it is important to ensure that the theoretical and practical parameters of such are met to ensure its coherence. In other words, there ought to be identifiable victims who have suffered harm caused by illegal or wrongful acts committed by perpetrators. Dinah Shelton outlines five factors which determine the likelihood of reparations being adopted in cases of historical injustice: (1) the perpetrator is still identifiable and living; (2) the victims, or their immediate descendants, are identifiable and living; (3) there is political pressure and strong, cohesive support from victims in demanding reparations; (4) the historical injustice is compelling and welldocumented; (5) there exists continued harm and a causal connection between present harm and the past injustice. $^{75}$

The schism between historical injustices and the provision of redress through both legal and political means is apparent in the case of the Japanese-Americans interned by the US during the Second World War. Despite the fact that some of those interned were unsuccessful in bringing legal proceedings against the government in the years after the war, it was not until the late $1980 \mathrm{~s}$, after years of political lobbying, that the US government agreed to pay compensation to each surviving internee. ${ }^{76}$ However, the payment itself, only $\$ 20,000$ for each victim, was a symbolic gesture, a 'token' that did not correspond to the severity of individuals' suffering. ${ }^{77}$ Moreover, PeruvianJapanese who were abducted by American forces to be interned in the US during the same period

\footnotetext{
75 Shelton n.35, p464.

${ }^{76}$ See Eric K. Yamamoto and Liann Ebesugawa, Report on Redress The Japanese American Internment, in de Greiff n.59, 257-283.

77 Alfred Brophy, Some Conceptual and Legal Problems in Reparations for Slavery, NYU Annual Survey of American Law, 58(4) (2003), 497-556, p500.
} 
were originally excluded from the scheme, only obtaining $\$ 5,000$ each after successfully challenging the law through the courts. Also excluded from the process were those victims who had died before the passing of the law in 1988, narrowing the pool of victims who were awarded compensation. Spouses, children and parents were only eligible for awards where the victim had survived up to the enactment of the legislation, but died before payment had been made. ${ }^{78}$ The extent to which JapaneseAmerican reparations provide support for claims relating to enslavement and other abuses crossing generations is therefore limited, as reparations took place only forty-three years after the conclusion of the war and were only awarded within the lifespan of the victims.

The claim that it would be unjust to make present actors responsible for the wrongs of history holds significant sway in the public debate surrounding the issue of reparations for transatlantic enslavement. Kukathas argues that agents - victim and perpetrator - must be identifiable, and 'one generation cannot be asked to atone for the sins of earlier ones' ${ }^{79}$ While this critique might apply to a case against the descendants of slavers, it does not quash the more prevalent claims against states and corporations for their role in enslavement. Although the individual perpetrators of the slave trade have long since died, states have remained constant - particularly those European states which perpetrated the 'trade'. A number of corporations that participated in human enslavement also continue to exist into the present, either directly or indirectly. Like a corporation, a state is "treated as a unity, consistent with its recognition as a single legal person in international law". ${ }^{80}$ The individuals operating within a state's organs of government therefore operate within the state as a legal entity, rather than constituting it. The temporal restrictions on liability which apply in the case of natural persons do not, therefore, apply to the state, which has a lifetime of its own. The organisational structures of the European 'slaver' states have remained largely undisturbed since the period of transatlantic enslavement, and the rules of state succession are unbroken. This formulation of liability in the hands of European nations and corporations should also be considered in relation to Arab slavers, who were the architects of an analogous 'trade' in African people in central and eastern Africa.

Identifying living victims of enslavement or their immediate descendants is problematic for those advocating redress. Those people that directly suffered from the system of chattel enslavement perpetrated by European nations, and their immediate descendants, are now long-past. Meeting this requirement in relation to individual victims is therefore close to impossible. The claims of states that were the primary victims of the harms of enslavements overcome this limitation through the same rules of state succession, which continue the liability of perpetrator states. For instance, the

${ }^{78}$ Civil Liberties Act of 1988 (public law 100-383), 10 $0^{\text {th }}$ August 1988102 stat 905, s.7. Yamamoto and Ebesugawa n.72, p272.

${ }^{79}$ Chandran Kukathas, Who? Whom? Reparations and the Problem of Agency, Journal of Social Philosophy, 37(3) (2006), 330-341.

${ }^{80}$ Crawford n.39, p83. 
CARICOM claim focuses on the claims of its Caribbean member states against the European states that participated in the injustices in relation to their territories. Such a characterisation of the identity of victims would likely open the door to claims from West African states who had their populations ravaged by the institution of transatlantic enslavement, as well as the South American countries that were the primary destination for enslaved Africans. ${ }^{81}$ The CARICOM claim could also set a precedent for other regional organisations, such as the African Union, to claim the victim identity of member states. Claims constructing collectives of victims within a state may also overcome the direct victim limitation, although establishing a sufficiently coherent identity as to qualify as a legal entity may be difficult to establish.

Collective legal identity is generally only recognised in relation to indigenous and tribal peoples, and may not extend to the disperse communities of the descendants of enslaved persons in the African diaspora. The most apparent groups, which can establish such collective rights, have been indigenous people, who share the same culture, laws and history. ${ }^{82}$ That said other groups of individuals who have less cultural and identity bonds have been collectively recognised as having rights to reparations, such as victims of particular crimes (gender based or sexual violence, child soldiers), war widows, orphans and those disappeared. ${ }^{83}$ In such cases the strength and unity of such victims has been based on them organising themselves into collectives to demand reparations, thereby being a political pressure group, often turning to the courts to seek redress.

In light of Shelton's third element of political pressure and strong, cohesive support from victims in demanding reparations, ${ }^{84}$ claims relating to transatlantic enslavement face significant challenges. In the Caribbean context, official state support for the reparations agenda and the organisation of the CARICOM Reparations Commission, as well as national reparations commissions amongst member states, speaks to the increasing political will of victim states. However, these states face internal volatility and fracturing between the official narratives and the expectations and wishes of those reparationists and descendants operating at the grassroots. The requisite capacity to exert political pressure on the wrongdoing states may still be lacking in the CARICOM claims, as European states continue to deny responsibility to make reparations on the basis that the enslavement was 'legal at the time'. David Cameron's visit to Jamaica, for instance, made Britain's refusal to engage with the reparations claims clear, indicating that there is not presently sufficient political leverage to get to the

\footnotetext{
${ }^{81}$ Lovejoy finds that 11,698,000 individuals were exported from Africa between 1450-1900. Around 35.3\% of all enslaved victims of the 'transatlantic trade' were delivered to Brazil, and $22.1 \%$ were delivered to the Spanish Empire predominantly in South and Central America. See Paul E. Lovejoy, The Volume Of The Atlantic Slave Trade: A Synthesis, Journal of African History 23 (1982) 473-501; and Hugh Thomas, The Slave Trade, The Story of the Atlantic Slave Trade: 1440-1870, (Simon and Schuster Paperbacks, 1997).

${ }^{82}$ UN Declaration on the Rights of Indigenous People 2007.

${ }^{83}$ Nairobi Declaration. See the practice in Sierra Leone, TRC Report Vol.II, Chapter 4, paras.69-70; and in Timor Leste - Chega! Commission for Reception, Truth and Reconciliation in East Timor (CAVR), (2005), Part $11, \S 12.9$.

${ }^{84}$ Shelton n.35, p464.
} 
point that responsible states involved in the slave trade will want to make a settlement on reparations. $^{85}$

The historical documentation of the transatlantic slave trade is extensive and sufficiently maintained so as to establish the nature and extent of harms committed. Shelton's fourth factor is therefore easily satisfied in relation to the brutal trade. Although establishing legal wrongdoing may be out of reach, the moral and political claim to the severity of the injustice is compelling. Reparations may be awarded in cases where the perpetrators purported the legality of the abuses provided there is a sufficiently strong moral justification, such was the case in relation to German atrocities committed during World War II. Establishing continuing harm and a causal connection to the past injustice as required to satisfy Shelton's fifth factor may be more difficult in relation to a system abolished in the 1800s. Claims based on the collective impact of an injustice, as are advanced by CARICOM, require a sufficient causal nexus to the slave trade and Western states' involvement in such, as well as evidence of that harm having translated through the generations to contemporary institutions of racism, deprivation and discrimination.

There is increasing evidence to support the intergenerational impact of major injustices, with transgenerational harms being noted in the children and grandchildren of those who have suffered from political repression or conflict. ${ }^{86}$ The extent to which this travels to generations beyond grandchildren to the extent that claims for transatlantic enslavement require remains unclear. However, the effects of structural injustices can be more easily traced in such a case including the economic impact of enslavement and the systems of labour put in place in the Caribbean on the contemporary states. ${ }^{87}$ The lasting impacts of historical injustices on nations were also recognised at the Durban 2001 World Conference on Racism, which stated that '...historical injustices have undeniably contributed to poverty, underdevelopment, marginalization, social exclusion, economic disparities, instability and insecurity that affect many people in different parts of the world, particularly in developing countries, ${ }^{88}$ This falls far short of the evidentiary requirements typically set in legal proceedings, and claimants therefore find themselves stumbling upon the limits of the law in addressing historical injustices. However, such research may still be persuasive in the political arena.

Starzyk et al and Nussio et al suggest the relevance of the political ideology of the perpetrator state in determining the likelihood of reparations being granted. Starzyk et al suggest that reparations are more likely to be publicly accepted or sociably feasible where they do not compromise social

\footnotetext{
${ }^{85}$ Richard Falk, Reparations, International Law, and Global Justice: A New Frontier, in de Greiff n.59, 478-503, p494.

${ }^{86}$ Michael A. Simpson, The Second Bullet: Transgenerational Impacts of the Trauma of Conflict within a South African and World Context, in Yael Danieli International Handbook of Multigenerational Legacies of Trauma (Kluwer Academic/Plenum Publishing Corporation 1998), 487-512.

${ }^{87}$ Sidney Mintz, Caribbean Transformations (Aldine Publishing 1974), p31.

88 World Conference against Racism, Racial Discrimination, Xenophobia and Related Intolerance, Durban Program of Action at Article 158
} 
values. ${ }^{89}$ This can create barriers to historical claims where the dominant narratives conceive of people as individuals with outcomes disconnected from family and racial histories. Nussio et al also point to other factors that prompt reparations, such as more left-leaning political ideology or groupbased or collective understandings of guilt. This factor underscores the significance of public support in the viability and sustainability of reparations. ${ }^{90}$ Thus for the UK and other Western countries involved in the transatlantic slave trade, there would need to be significant social mobilisation and support for reparations by Caribbean states to overcome the typically individualistic paradigm of political thought. New law may be a space to create such a dialogue and framework to mobilise around. A multinational treaty between the Caribbean, African, European and Arab states may be a way forward to concentrate minds on appropriate development and symbolic reparations needed to address the consequences of the slave trade.

\subsection{What form of reparations would be appropriate?}

The harms of transatlantic slave trade over the course of the centuries that it was perpetuated defy quantification, and any attempt to do so would likely result in figures in the trillions. In 1999, for instance, the Afrikan World Reparations and Repatriation Truth Commission called for 'those nations of Western Europe and the Americas and institutions, who participated and benefitted from the slave trade and colonialism' to pay $\$ 777$ trillion to Africa within five years. ${ }^{91}$ Yet as Howard-Hassmann points out this amount is sixty-two times the US GDP in 2005 and there is no indication of how such an amount was arrived at. ${ }^{92}$ Indeed she goes so far that such a huge amount of compensation undermines the feasibility of such reparations. Instead such measures should be 'reasonable' and 'payable without significant disadvantage to those making the payment. ${ }^{93}$ Moreover, assessing the degree of damages is in most part speculative as it necessarily attempts to quantify the loss and suffering of millions of potential individuals and societies over the course of multiple centuries; this would likely frustrate the prospect of getting responsible actors around the table to negotiate. ${ }^{94}$

The impact of intervening factors on the suffering of the descendants of enslaved persons, and the passage of time, compound the difficulties of assessing reparations awards, making an accurate determination of a proportionate award impossible. The dispersal of the victim populations, the degrees of separation between individual enslaved persons and their descendants, and the structural

\footnotetext{
${ }^{89}$ Katherine Starzyk, Danielle Gaucher, Gregory Boese and Katelin Neufeld, Framing reparation claims for crimes against humanity: a social psychological perspective, in J. Wemmers (ed.), Reparations for Victims of Crimes Against Humanity, (Routledge 2014), 113-125.

90 Enzo Nussio, Angelika Rettberg, and Juan E. Ugarriza, Victims, Nonvictims and Their Opinions on Transitional Justice: Findings from the Colombian Case, International Journal of Transitional Justice, 9(2) (2015) 336-354, p343.

${ }^{91}$ Participants of the First Historic International Reparations and Repatriation Truth Commission Conference, 'The Accra Declaration on Reparation and Repatriation', 12 August 1999.

${ }^{92}$ Rhoda E. Howard-Hassmann, Reparations to Africa, University of Pennsylvania Press, 2008, p28.

93 Ibid.

${ }^{94}$ Du Plessis n.33, p651.
} 
and systemic nature of the continuing harms make individual compensation unfeasible in the context of transatlantic enslavement. Identifying individual victims and providing sufficient evidence to establish harm and a causal nexus would be arduous and often fruitless. Moreover, quantification of harms can diminish the gravity of the injustices and undermine reconciliation and meaningful acknowledgement of suffering. 'Payment' in this context can become a 'dirty word'; perpetrators can be seen as attempting to obviate their culpability through 'blood money' designed to pay off their guilt, and victims can be perceived as opportunistic to benefit from the abuses. ${ }^{95}$

It would be very difficult to establish direct or indirect intergenerational harms suffered by an individual descendant and caused by the harm inflicted on their ancestor. Establishing the widespread existence of such specific and inherited contemporary harms in large cross-sections of society would be even more untenable. Viewing reparations through a transformational justice lens would therefore be more appropriate in this context, tackling the causes and consequences of the slave trade as a whole as opposed to only the direct symptoms suffered by those enslaved. The mass exploitation and atrocities committed against enslaved people are thereby viewed as having direct harms upon their children, and potentially also upon subsequent generations. The system of enslavement is also conceived as having wider repercussions for Caribbean states. In this context it is not so much the direct acts of enslavement of particular persons that continue to harm the state, but the structures of abuses and the institutional systems put in place at the time. Du Plessis identifies that it is more feasible to seek reparations to address the legacy of enslavement, rather than to try and redress the historical injustice itself. ${ }^{96}$ This framework lends itself to the construction of collective reparations and symbolic measures to redress the suffering of people alive in the present.

CARICOM's Ten Point Reparation plan is distributive in nature given the historical nature of the abuse. As Teitel notes:

With the passage of time, reparatory projects move farther from the traditional model of corrective justice. After time, wrongdoers don't pay; innocents do. And, after time, redress goes not to original victims but to their descendants. With the passage of time, therefore, reparatory schemes look less like conventional corrective justice and more like a social distribution and political question ... more like distributive schemes. ${ }^{97}$

Such measures are therefore more appropriately dealt with in the political arena, rather than through judicial mechanisms and individual reparations. The CARICOM Ten Point Plan seeks a distributive, and perhaps even transformative, justice settlement that addresses structural harms connected to

\footnotetext{
95 Claire Moon, 'Who'll Pay Reparations on My Soul?' Compensation, Social Control and Social Suffering, Social and Legal Studies 21(2) (2012) 187-199, p194.

${ }^{96}$ Du Plessis n.33, p652.

${ }^{97}$ Ruti Teitel, Transitional Justice (Oxford University Press, 2002), p141.
} 
enslavement. More broadly such reparations are transformative in renegotiating the status of Caribbean states and the ongoing unequal power relations with former colonial powers.

As structural measures premised upon the legacies of enslavement rather than individual connections to enslaved persons, the CARICOM claim is collective in nature. Collective reparations are remedial measures aimed at responding to the harm suffered by a group, community or people and providing 'shared benefits' to the victim population that reflect the collective harm shared by the group. ${ }^{98}$ This harm can be attributable to the collective as such, or to a group of individuals who make up a collective, and may be based on violations directed at their identity or their belonging to the group. Jewish people constituted such a collective during the Holocaust. ${ }^{99}$ The CARICOM claim seeks to classify modern citizens suffering from the legacies of enslavement as such a collective. The lack of specificity in identifying individual recipients of state-based reparations poses some challenge, as the collective right to reparations (unlike the identification of harm) seems to be limited to a multiplicity of individuals in a group rather than the group itself. ${ }^{100}$ Collective reparations can include symbolic measures of acknowledgment, apologies, compensation, pensions, rehabilitative measures including physical and psychological health services, social and legal services, educational support and other infrastructural support. In Peru collective reparations have included educational scholarships, specialised healthcare, and memorials. ${ }^{101}$ Measures responsive to the needs of victimised populations can assist in addressing the destruction of communal bonds and culture, which was a significant feature of transatlantic enslavement and associated genocide against indigenous communities. $^{102}$

Reparations for historical injustices can serve as a lens for accountability and provide psychological healing to victimised populations as collectives and individuals. As Hamber and Wilson assert, the use of symbolic reparations, such as memorials, serve to:

... acknowledge and recognise the individual's suffering and place it within a new officially sanctioned history of trauma. Symbolic representations of the trauma, particularly if the symbols are personalised, can concretise a traumatic event, and help re-attribute responsibility. The latter stage is important because labelling

\footnotetext{
98 Friedrich Rosenfeld, Collective reparation for victims of armed conflict, International Review of the Red Cross 92(879) (2010) 731-746, p733-734.

${ }^{99}$ Ibid. p734.

${ }^{100}$ Ibid. p736.

${ }^{101}$ Cristián Correa, Reparations in Peru: From Recommendations to Implementation, ICTJ, June 2013.

${ }^{102}$ Hugo van der Merwe, Reparations through different lenses: The culture, rights and politics of healing and empowerment after mass atrocities, in Wemmers n.85, 200-218, p202.
} 
responsibility can appropriately redirect blame towards perpetrators and relieve the moral ambiguity and guilt survivors often feel. ${ }^{103}$

Memorials can also serve as 'vehicles for the intergenerational transmission of historical memory', ${ }^{104}$ cementing a collective's sense of identity, value, and belonging, as well as helping to ensure that atrocities are not repeated. Yet there were millions of victims of the transatlantic slave trade, many of whom there may be no record, so such a memorial would unlikely to be able to sufficient document each individual. Instead a visual memorial in a public place can serve as permanent physical reminders in society's consciousness to acknowledge, remember and not forget the atrocities of the past, such as the 'Ark of Return' memorial in UN plaza in New York opened in 2015 or the underwater 'Vicissitudes' sculpture in Grenada has now become imbued as a memorial to slaves who were thrown overboard. Official guarantees of non-repetition can also assist in preventing the reoccurrence of harms, instituted alongside concrete legislative and other measures to ensure their success. However, such measures need to be located not just in the Caribbean, but in African countries and states responsible for slavery in Europe and MENA, so as to keep alive the public memory of such atrocities and for them to be never repeated.

Acknowledgement of wrongdoing is vital to the success of a reparations programme, and meaningful apologies are an integral aspect of such recognition. Successful apologies usually include an acceptance of responsibility, sincere statements of regret, a willingness to make amends and prevent future violations without any excuses or offensive explanations. ${ }^{105}$ A successful apology can meaningfully contribute to reconciliation and reparation, whereas unsuccessful apologies can simply add insult to injury. Insincere apologies or half-hearted acknowledgements of responsibility, for instance, in trying to close a chapter on the past might 'make survivors feel that reparations are being used to buy their silence and put a stop to their continuing quest for truth and justice. ${ }^{106}$ Perhaps the CARICOM claim should engage European and MENA states to engage on the reparations issues as a symbolic way to take moral responsibility, not legal, for the transatlantic slave trade and apologies that by today's standards is reprehensible and efforts will be made on developmental terms with such affected states to heal the long term consequences of the slave trade. This may have to take the form of an international treaty that bars any individual, collective or state claim against those states involved in the slave trade, in exchange for focused development or cancellation of debt and symbolic reparations.

\footnotetext{
${ }^{103}$ Brandon Hamber and Richard Wilson, Symbolic closure through memory, reparation and revenge in postconflict societies, Journal of Human Rights 1 (1) (2002), 35-53, p38.

${ }^{104}$ Hamber n.17, p219.

${ }^{105}$ Michael R. Marrus, Official apologies and the quest for historical justice, Journal of Human Rights 6 (1)(2007) 75-105; Nicholas Tavuchis, Mea Culpa: A Sociology of Apology and Reconciliation, (Stanford University Press, Stanford, 1991), p17; and Michael Cunningham, Saying sorry: the politics of apology, The Political Quarterly 70 (1999), 285-293.

${ }^{106}$ Hamber and Wilson n.98, p46.
} 
Development funds have been part of reparations ordered by human rights courts. By way of example in the Moiwana Community $v$ Suriname case - after armed forces of Suriname attacked the village of Moiwana, massacred over 40 people, razed the village to the ground, forced survivors to flee into exile or internal displacement, and failed to adequately investigate the massacre - the InterAmerican Court of Human Rights ordered the state to set up a development fund to provide health, housing and educational programmes for community members. ${ }^{107}$ The development fund was to be represented by three members: one selected by the victim, one by the state, and the third agreed between the victims and the state. ${ }^{108}$ To complement this fund the Court ordered the state to provide more symbolic measures of a public apology and acknowledgement of its responsibility, as well as to construct a memorial. ${ }^{109}$ In other cases before the Inter-American Court, the Court has ordered extensive rehabilitative measures to communities affected by gross violations of human rights, such as housing and development programmes, healthcare centres, cultural education and infrastructure. ${ }^{110}$ Such extensive infrastructure would probably be beyond the bounds of a treaty on reparations for the transatlantic slave trade, but directing development aid to such countries to tackle illiteracy, technology asymmetry and psychological rehabilitation as demanded by CARICOM.

Such developmental or symbolic reparations can be difficult to distinguish from state obligations to tackle poverty and exclusion, and to provide certain services. When controlled by perpetrators who maintain hierarchical positions of power over victimised populations, such measures can represent more paternalism and charity, framing victims as a dependent group rather than as individuals with autonomy. ${ }^{111}$ As Gifford identifies:

When European governments respond, as they do, to the injustices suffered by Black people, it is by way of development aid or anti-discrimination laws, so that generous Europeans appear to be bestowing benefits on poor suffering Africans. There is often an overtone of condescension: the Africans are suffering because their leaders have messed things up, but we still help. ${ }^{112}$

While 'development' can be constructed and developed with input from the victims, they are framed as collective beneficiaries rather than as individuals with rights and agency. Framing measures as reparative - as connected to specific acts of wrongdoing - as well as involving affected communities in the construction of programmes can therefore be essential in countering these notions of dependency and marginalisation. Engagement with transformational reparations may be a way

\footnotetext{
${ }^{107}$ Moiwana Community v Suriname, Judgement of June 15, 2005, Series C No 124, (Preliminary Objections, Merits, Reparations and Costs), para.214.

108 Ibid. para. 215.

${ }^{109}$ Ibid. para.216-218.

${ }^{110}$ Plan de Sánchez Massacre, paras.105 and 110.

${ }^{111}$ Verdeja n.91, p460.

${ }^{112}$ Anthony Gifford, Pipe Dream or Necessary Atonement? Index on Censorship 36(1) (2007), 89-96, p94.
} 
forward in reimagining narratives of victimisation and hundreds of years of exploitation and continuing discrimination towards inclusivity and respect of the dignity of descendants of the transatlantic slave trade and historic enslavement.

\section{CONCLUSION}

Reparations are a symbolic way of accounting for a society's past wrongdoing. No amount of money is ever going to undo the harm caused by gross violations of human rights. While today's generation and government may be decades or even centuries removed from the atrocities of enslavement, colonialism and the genocide of indigenous peoples, they nevertheless indirectly benefit from the economic development arising from the economic exploitation of labour, capital, and land. Reparations look not only to the past, but to reaffirm the contemporary legal order and the morality of the state by recognising that such past atrocities were reprehensible. They also serve to distinguish the state from its predecessor, affirming that the society has advanced to meaningfully acknowledge the dignity and equality of all human beings. Such measures may only be symbolic, but they can provide for practical redress, affirmative action or the restitution of land to indigenous populations.

It is clear that the issue of reparations for the transatlantic slave trade is not going to go away. CARICOM's 10-point plan focusing on symbolic redress and rebalancing of ongoing structural inequalities domestically and internationally provides a way forward for opening the discussion on redressing the transatlantic slave trade in political and moral terms. Given the number of states involved, the lack of international legal basis for claiming reparations, and the passage of time, a multinational treaty may be the best way forward, rather than pressuring each individual state responsible for the slave trade. In the face of increasing racism and xenophobia across the world, political maturity and moral leadership in Western countries in making overtures to symbolic reparations to descendants of the slave trade could go a long way in reaffirming the wrongs of the past and promoting the value these populations bring to the international community. 